\title{
Front Matter: Volume 10122
}

, "Front Matter: Volume 10122," Proc. SPIE 10122, Vertical-Cavity SurfaceEmitting Lasers XXI, 1012201 (16 March 2017); doi: 10.1117/12.2275496

SPIE. Event: SPIE OPTO, 2017, San Francisco, California, United States 


\section{PROCEEDINGS OF SPIE}

\section{Vertical-Cavity Surface-Emitting Lasers XXI}

Kent D. Choquette

Chun Lei

Editors

1-2 February 2017

San Francisco, California, United States

Sponsored and Published by

SPIE 
The papers in this volume were part of the technical conference cited on the cover and title page. Papers were selected and subject to review by the editors and conference program committee. Some conference presentations may not be available for publication. Additional papers and presentation recordings may be available online in the SPIE Digital Library at SPIEDigitallibrary.org.

The papers reflect the work and thoughts of the authors and are published herein as submitted. The publisher is not responsible for the validity of the information or for any outcomes resulting from reliance thereon.

Please use the following format to cite material from these proceedings:

Author(s), "Title of Paper," in Vertical-Cavity Surface-Emitting Lasers XXI, edited by Kent D. Choquette, Chun Lei, Proceedings of SPIE Vol. 10122 (SPIE, Bellingham, WA, 2017) Seven-digit Article CID Number.

ISSN: 0277-786X

ISSN: 1996-786X (electronic)

ISBN: 9781510606852

ISBN: 9781510606869 (electronic)

Published by

SPIE

P.O. Box 10, Bellingham, Washington 98227-0010 USA

Telephone +1 3606763290 (Pacific Time) · Fax +1 3606471445

SPIE.org

Copyright (c) 2017, Society of Photo-Optical Instrumentation Engineers.

Copying of material in this book for internal or personal use, or for the internal or personal use of specific clients, beyond the fair use provisions granted by the U.S. Copyright Law is authorized by SPIE subject to payment of copying fees. The Transactional Reporting Service base fee for this volume is $\$ 18.00$ per article (or portion thereof), which should be paid directly to the Copyright Clearance Center (CCC), 222 Rosewood Drive, Danvers, MA 01923. Payment may also be made electronically through CCC Online at copyright.com. Other copying for republication, resale, advertising or promotion, or any form of systematic or multiple reproduction of any material in this book is prohibited except with permission in writing from the publisher. The CCC fee code is 0277-786X/17/\$18.00.

Printed in the United States of America.

Publication of record for individual papers is online in the SPIE Digital Library.

\section{SPIE. DIGITAL \\ SPIEDigitalLibrary.org}

Paper Numbering: Proceedings of SPIE follow an e-First publication model. A unique citation identifier (CID) number is assigned to each article at the time of publication. Utilization of CIDs allows articles to be fully citable as soon as they are published online, and connects the same identifier to all online and print versions of the publication. SPIE uses a seven-digit CID article numbering system structured as follows:

- The first five digits correspond to the SPIE volume number.

- The last two digits indicate publication order within the volume using a Base 36 numbering system employing both numerals and letters. These two-number sets start with 00, 01, 02, 03, 04, $05,06,07,08,09,0 A, 0 B \ldots$ OZ, followed by 10-1Z, 20-2Z, etc. The CID Number appears on each page of the manuscript. 


\title{
Contents
}

\author{
$\checkmark$ Authors \\ vii Conference Committee
}

\section{SESSION 1 COMMERCIAL VCSELS FOR APPLICATIONS}

1012202 50Gb/s PAM-4 oxide VCSEL development progress at Broadcom (Invited Paper) [10122-1]

1012203 VCSELs for optical communication at Fuji Xerox (Invited Paper) [10122-2]

1012204 VCSELs as light source for time-of-flight sensors [10122-3]

1012205 Progress in optimization of high-power high-speed VCSEL arrays [10122-4]

1012206 Progress on high-power 808nm VCSELs and applications [10122-5]

\section{SESSION 2 MODULATION AND MANUFACTURING}

1012207 Modulation enhancements of photonic crystal VCSELs [10122-6]

1012208 Continuous wave and modulation performance of $1550 \mathrm{~nm}$ band wafer-fused VCSELS with MBE-grown InP-based active region and GaAs-based DBRs [10122-7]

1012209 Towards a SFP+ module for WDM applications using an ultra-widely-tunable high-speed MEMS-VCSEL [10122-8]

10122 OA Modelling of the modulation properties of arsenide and nitride VCSELs [10122-9]

10122 OB Tunnel junction 850-nm VCSEL for aperture uniformity and reliability [10122-10]

10122 OC Comparative study of contact geometry for bottom-emitting 980-nm VCSELs [10122-11]

\section{SESSION 3 50GBPS AND BEYOND}

10122 OE VCSEL modal dynamics and implications for 100Gbps links (Invited Paper) [10122-13]

10122 OF Single-mode 850-nm vertical-cavity surface-emitting lasers with $\mathrm{Zn}$-diffusion and oxiderelief apertures for $>50$ Gbit/sec OOK and 4-PAM transmission (Invited Paper) [10122-14]

10122 OG High-speed optical interconnects with 850nm VCSELS and advanced modulation formats (Invited Paper) [10122-15] 
$10122 \mathrm{OH} \quad$ Hybrid vertical-cavity laser integration on silicon (Invited Paper) [10122-16]

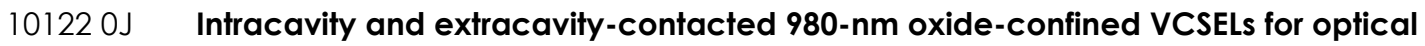
interconnects and integration (Invited Paper) [10122-18]

\section{SESSION 5 MODES AND POLARIZATION}

10122 OK Robustness versus thermal effects of single-mode operation of vertical-cavity surfaceemitting lasers with engineered leakage of high-order transverse optical modes [10122-19]

$10122 \mathrm{OL}$ Transverse mode control in proton-implanted and oxide-confined VCSELs via patterned dielectric anti-phase filters [10122-20]

10122 OM Semiconductor-metal subwavelength grating VCSELs: new concept of emission mirror enabling vertical current injection [10122-21]

10122 ON Transverse mode selection in vertical-cavity surface-emitting lasers via deep impurityinduced disordering [10122-22]

1012200 Investigations on polarization oscillation amplitudes in spin-VCSELs [10122-23]

10122 OP Correlation between polarization modes in VCSEL with optical feedback [10122-24] 


\section{Authors}

Numbers in the index correspond to the last two digits of the seven digit citation identifier (CID) article numbering system used in Proceedings of SPIE. The first five digits reflect the volume number. Base 36 numbering is employed for the last two digits and indicates the order of articles within the volume. Numbers start with 00, 01, 02, 03, 04, 05, 06, 07, 08, 09, OA, OB...0Z, followed by 10-12, 20-2Z, etc.

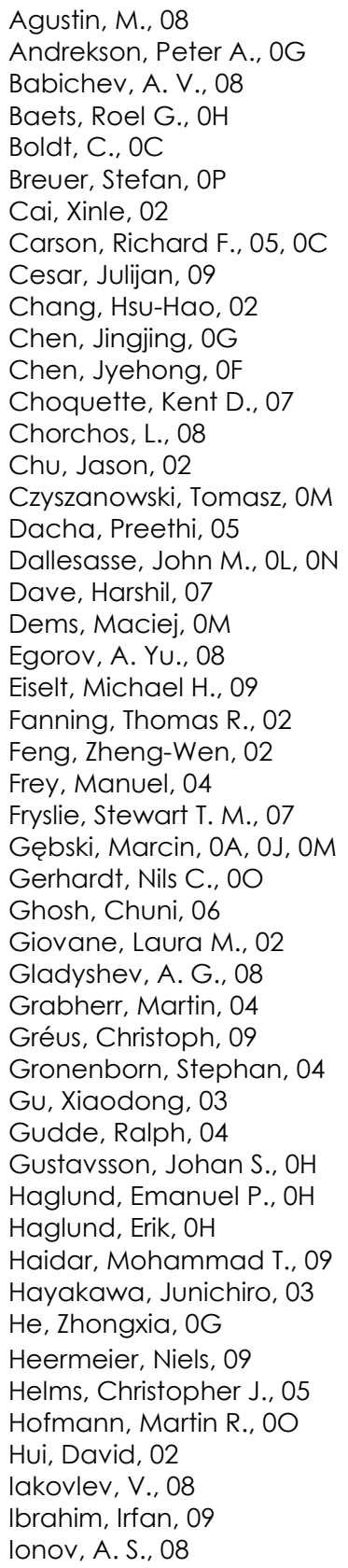

Jogan, Naoki, 03

Kalosha, V.P., OK

Karachinsky, L. Ya., 08

Karlsson, Magnus, OG

Kesler, Benjamin, OL, ON

Kolb, Johanna, 04

Kondo, Takashi, 03

Kovsh, Alexey, 06

Koyama, Fumio, 03

Kropp, J.-R., OK

Kumari, Sulakshna, $\mathrm{OH}$

Küppers, Franko, 09

Kyi, W., OB

Larsson, Anders G., OG, OH

Lavrencik, Justin, $O E$

Ledentsov, N. N., 08, OF, OK

Ledentsov, N. N., Jr., OK

Lehman Harren, Ann, 02

Lengyel, Tamás, OG

Li, Nein-Yi, 05

Lindemann, Markus, 00

Lott, James A., 05, 0A, 0C, 0J

Malekizandi, Mohammadreza, 09

Martin, Eric J. J., 05

Michalzik, Rainer, 00

Miglo, Alexander, 06

Mikhailov, S., 08

Miller, Michael, 04

Moench, Holger, 04

Moser, Philip, OA, OC, OJ

Murakami, Akemi, 03

Murty, M. V. Ramana, 02

Neumeyr, Christian, 09

Novikov, I. I., 08

O'Brien, Thomas R., OL, ON

Ortsiefer, Markus, 09

Panajotov, Krassimir, OM

Pao, J., OB

Paul, Sujoy, 09

Podva, David, 05

Pusch, Tobias, 00

Ralph, Stephen E., OE

Riaziat, M., OB

Roelkens, Gunther, $\mathrm{OH}$

Rontani, Damien, OP

Rosales, Ricardo, OC, OJ

Rosprim, James P., 05

Sakurai, Jun, 03

Sarzała, Robert P., OA 
Schmeckebier, Holger, OA, OC, OJ

Schmidt, Henning, 09

Schmidt, Jörg, 09

Schutt-Ainé, José E., 07

Sciamanna, Marc, OP

Seurin, Jean-Francois, 06

Shchukin, V. A., OK

Shi, Jin-Wei, OF

Sirbu, A., 08

Śpiewak, Patrycja, 0A, 0J

Sridhara, Aaditya, 02

Stepniak, G., 08

Szczerba, Krzysztof, 0G

Taslim, Sumitro-Joyo, 02

Turkiewicz, J. P., 08

Uy, Chi-Hak, OP

Van Leeuwen, Robert, 06

Voropaev, K. O., 08

Wang, Charlie, 02

Wang, Jingyi, 02

Wang, Li, 05

Wang, Qing, 06

Warren, Mial E., 05, OC

Wasiak, Michat, OA, OJ

Wei, Chia-Chien, OF

Weigl, Alexander, 04

Wilcox, Thomas, 05

Wong, P. S., OB

Wu, T. C., OB

$\mathrm{Xu}$, Guoyang, 06

Yan, J., OB

Yang, Ying-Jay, OF

Zhou, Delai, 06

Zirath, Herbert, $0 G$ 


\section{Conference Committee}

Symposium Chairs

Jean-Emmanuel Broquin, IMEP-LAHC (France)

Shibin Jiang, AdValue Photonics, Inc. (United States)

Symposium Co-chairs

Connie J. Chang-Hasnain, University of California, Berkeley

(United States)

Graham T. Reed, Optoelectronics Research Centre, University of

Southampton (United Kingdom)

Program Track Chair

Klaus P. Streubel, OSRAM AG (Germany)

Conference Chairs

Kent D. Choquette, University of Illinois at Urbana-Champaign

(United States)

Chun Lei, EMCORE Corporation (United States)

Conference Program Committee

Nicolae Chitica, Finisar Corporation (Sweden)

Aaron James Danner, National University of Singapore (Singapore)

Martin Grabherr, Philips Technologie GmbH U-L-M Photonics

(Germany)

James K. Guenter, Finisar Corporation (United States)

Anders Larsson, Chalmers University of Technology (Sweden)

James A. Lott, Technische Universität Berlin (Germany)

M. V. Ramana Murty, Avago Technologies Ltd. (United States)

Krassimir Panajotov, Vrije Universiteit Brussel (Belgium)

Darwin K. Serkland, Sandia National Laboratories (United States)

Jean-Francois Seurin, Princeton Optronics, Inc. (United States)

Noriyuki Yokouchi, Furukawa Electric Company, Ltd. (Japan)

Jongseung Yoon, The University of Southern California (United States)

Mial E. Warren, TriLumina Corporation (United States)

Session Chairs

1 Commercial VCSELs for Applications

Chun Lei, EMCORE Corporation (United States) 
2 Modulation and Manufacturing

James A. Lott, Technische Universität Berlin (Germany)

3 50Gbps and Beyond

Anders G. Larsson, Chalmers University of Technology (Sweden)

4 Emerging VCSEL Technologies

Stephen E. Ralph, Georgia Institute of Technology (United States)

5 Modes and Polarization

Kent D. Choquette, University of Illinois at Urbana-Champaign (United States) 